\title{
Erratum to: Whites and Blacks Have Similar Risk of Metachronous Advanced Colorectal Neoplasia
}

\author{
Joann Kwah • Paul C. Schroy III • Brian C. Jacobson • \\ Audrey H. Calderwood
}

Published online: 8 June 2014

(c) Springer Science+Business Media New York 2014

\section{Erratum to: Dig Dis Sci}

DOI 10.1007/s10620-014-3132-4

In the abstract, the authors stated that "During a median follow-up of 4.3 years, the overall prevalence of $\mathrm{ACN}$ at surveillance was similar among blacks and whites (11.3 vs. $9.8 \% ; P=0.59)$ with an odds ratio of 1.18 (95\% CI 0.65-2.26)." However, in Table 2a, they stated 1.18 [0.65-2.16]. The correct odds ratio is 1.18 [0.65-2.16] as listed in the table. The upper $95 \% \mathrm{CI}$ for the OR in abstract should be corrected from 2.26 to 2.16 .

The "military" under insurance in Table 1 should be removed. It is zero for both comparisons.

The online version of the original article can be found under doi:10.1007/s10620-014-3132-4.

\section{J. Kwah}

Division of Gastroenterology, Montefiore Medical Center,

111 East 210th Street, Bronx, NY 10467, USA

e-mail: jokwah@montefiore.org

P. C. Schroy III - B. C. Jacobson

Section of Gastroenterology, Boston Medical Center, 85 East

Concord Street, Seventh Floor, Boston, MA 02118, USA

e-mail: Paul.Schroy@bmc.org

B. C. Jacobson

e-mail: Brian.Jacobson@bmc.org

\section{A. H. Calderwood ( $\square)$}

Section of Gastroenterology, Boston Medical Center, 85 East

Concord Street, Room 7724, Boston, MA 02118, USA

e-mail: Audrey.Calderwood@bmc.org 